\title{
The half-life of follicle-stimulating hormone in ovary-intact and ovariectomized Booroola and control Merino ewes
}

\author{
R. C. Fry, L. P. Cahill, J. T. Cummins*, B. M. Bindon†, L. R. Piper $\dagger$ \\ and I. J. Clarke \\ Animal Research Institute, Werribee, Victoria 3030; *St Vincents Hospital, Melbourne, \\ Victoria 3002; $\uparrow$ C.S.I.R.O., Armidale, New South Wales 2350; and $\ddagger$ Medical Research Centre, \\ Prince Henry's Hospital, Melbourne, Victoria 3004, Australia
}

\begin{abstract}
Summary. To determine whether the high ovulation rate of the Booroola Merino ewe could be explained by FSH metabolism we have tested the proposition that FSH may have a longer half-life in the plasma of Booroola Merino ewes than in control ewes. The half-life of plasma FSH was determined by removal of the pituitary gland, to abolish FSH secretion into the peripheral circulation, and monitoring by repeated blood sampling the subsequent decline in plasma FSH concentrations. The half-life of FSH was similar in Booroola $(103 \pm 14$ (s.e.m.) min, $\mathrm{N}=8)$ and control $(116 \pm 8 \mathrm{~min}$, $\mathrm{N}=9$ ) ewes. However, when ewes that had been ovariectomized at least 6 months earlier were hypophysectomized, the half-life of FSH was increased from $110+8$ min in ovary-intact ewes $(\mathrm{N}=11)$ to $1101 \pm 49 \min (\mathrm{N}=6)(P<0.001)$ with no difference between the two Merino strains. We conclude that changes in the circulating half-life of FSH do not account for the high fecundity of the Booroola but that ovariectomy can alter the half-life of FSH secreted by the pituitary gland.
\end{abstract}

\section{Introduction}

The high ovulation rate of Booroola Merino ewes is thought to be due to a single major gene, the $\mathrm{F}$ gene (Piper \& Bindon, 1980), and it has been suggested that this might alter the metabolism of follicle-stimulating hormone (FSH) (Bindon, 1984). Removal of sialic acid residues by neuraminidase has been identified as one way in which the clearance rate of FSH can be increased (Morell et al., 1971; Yang \& Papkoff, 1973; Ulloa-Aguirre et al., 1984), and a deficiency of this enzyme in the liver of Booroola ewes could reduce the breakdown of FSH and therefore increase the biological half-life of the hormone (Bindon, 1984).

In this study, the half-life of endogenous FSH in the plasma of Booroola and control (AB20) strain Merino ewes was compared by following its subsequent decline after hypophysectomy. This approach to the measurement of plasma half-life of FSH has been used previously in humans (Yen et al., 1970) and has the advantage over administration of labelled FSH preparations in that the naturally occurring hormone of the animal is being studied at physiological levels. As apparent prolongation of the clearance rate of $\mathrm{LH}$ in plasma occurred after ovariectomy of Ile-de-France ewes (Montgomery et al., 1984), we also investigated the effect of long-term ovariectomy on the plasma half-life of FSH in both strains of ewes.

\section{Materials and Methods}

Animals. Mature Booroola $(\mathrm{F}+)$ and control $(++)$ were bred at the Pastoral Research Laboratory, C.S.I.R.O., Armidale. The ewes had been subjected to repeated laparoscopies to assess their ovulation rate and ensure that the correct copies of the fecundity gene were carried (Davis et al., 1982). The ovulation rate of the F+ ewes was 3 
BOOROOLA

Ovary-intact

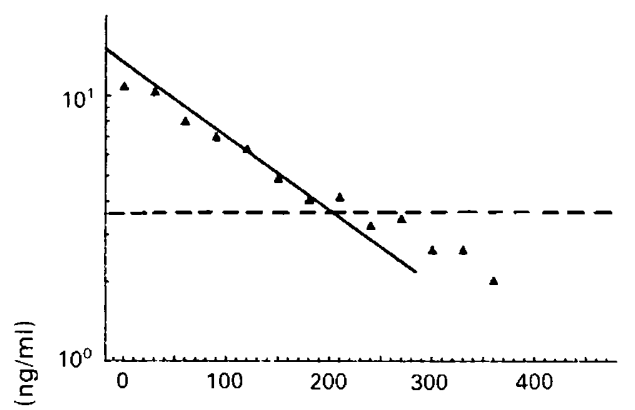

Ovariectomized

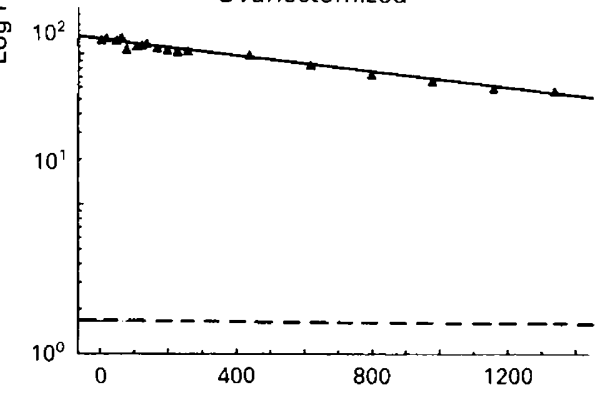

AB 20

Ovary-intact

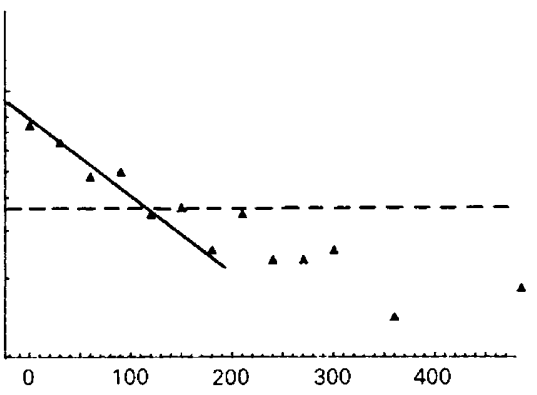

Ovariectomized

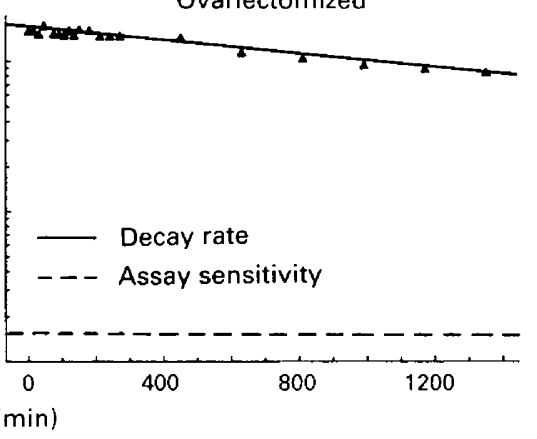

Fig. 1. Decay curves of plasma FSH following hypophysectomy for a representative animal from each of the four treatment groups.

or 4 and that of the ++ ewes was $<3$. Throughout the experiment, the ewes were fed pasture or lucerne hay and were brought indoors for blood sampling. Ovariectomized ewes underwent hypophysectomy at least 6 months after removal of the ovaries.

Experimental design. A $2 \times 2$ factorial design was adopted to compare the half-lives of FSH in Booroola $(\mathrm{N}=5)$, control $(N=6)$, ovariectomized Booroola $(N=3)$ and ovariectomized control $(N=3)$ ewes.

Surgery. Ovariectomy was performed under general anaesthesia induced by thiopentone sodium (Intraval; May \& Baker, Footscray, Australia) and the tract was exteriorized via a mid-ventral incision.

For hypophysectomy the ewes were anaesthetized using thiopentone sodium (Intraval) and maintained with a halothane-oxygen mixture. The anaesthetized ewes were positioned with their heads held by a metal framework and the dura mater along the anterior face of the pituitary was exposed by the transnasal, transsphenoidal route described by Clarke et al. (1983). This involved reflection of the left nasal bone to achieve access to the nasal cavity and the drilling out of sphenoid bone along the mid-line, to the pituitary gland. The dura mater was removed from the entire anterior face of the gland and the pituitary stalk and median eminence were removed by diathermy. This eliminated the essential blood supply to the gland which arises from the suprahypophysial arteries and thus prevented bleeding during removal of the gland which was achieved by blunt dissection and soft suction with metal suckers. The empty pituitary fossa was swabbed with alcohol to kill any remaining endocrine cells. The time taken from cautery of the stalk-median eminence to completion of hypophysectomy was approximately 2 min. Finally, the fossa was packed with gelatin foam (Gelfoam; size 4, Upjohn, Rydalmere, Australia), the cavity in the sphenoid bone was sealed with dental acrylic (R.D. Dental Acrylic; De Trey, Cambridge, U.K.) and the nasal bone was replaced. GnRH and TRH challenge of these hypophysectomized ewes some weeks after surgery failed to release detectable amounts of LH, FSH or prolactin into the blood of any animal, confirming that no viable pituitary tissue remained.

Blood sampling procedures. Blood samples $(8 \mathrm{ml})$ were collected via indwelling jugular venous catheters (Dwellcaths, 12G; Tuta Laboratories, Lane Cove, Australia). Cannulae were kept patent by flushing with heparinized ( 75 units $/ \mathrm{ml}$ ) physiological saline $(0.15 \mathrm{M}-\mathrm{NaCl}$ ) and closed with a 3-way tap (A.H.S., Sydney, Australia). Three blood samples were taken at 15-min intervals before hypophysectomy, and one when the surgeon indicated that hypophysectomy was complete. Samples were then taken at 15 -min intervals for $2 \mathrm{~h}$, at $30-\mathrm{min}$ intervals for the next $2 \mathrm{~h}$ and 
then at 3 - $\mathrm{h}$ intervals for $18 \mathrm{~h}$. Samples were put into heparinized (1000 units/ml) tubes and centrifuged to obtain plasma which was stored at $-15^{\circ} \mathrm{C}$ before assay.

Assays. Plasma FSH concentrations were measured by the double antibody RIA described previously by Bremner et al. (1980), using NIH-oFSH-SI 3 as standard. Samples were read from the portion of the standard curve where the intra-assay coefficient of variation (CV) was $<20 \%$. At maximum precision the intra-assay CV was $3 \cdot 7-5 \cdot 2 \%$ between 42 and $61 \mathrm{ng} \mathrm{FSH} / \mathrm{ml}$ (3 assays) and assay sensitivity, defined as when the within-assay coefficient of variation equalled $50 \%$, was $1 \cdot 4-2 \cdot 6 \mathrm{ng} \mathrm{FSH} / \mathrm{ml}$. The between-assay $\mathrm{CV}$ was $4 \cdot 1-5 \cdot 8 \%$.

Plasma LH and plasma prolactin concentrations were measured in single assays by the methods of Lee et al. (1976) and Clarke $e t$ al. (1982) respectively. Assay sensitivities were $0.85 \mathrm{ng} \mathrm{LH} / \mathrm{ml}$ and $14.2 \mathrm{ng}$ prolactin/ml respectively.

Analysis and statistics. The apparent half-life for FSH was calculated assuming exponential decay. Plotting of the individual $\log [\mathrm{FSH}]$ vs time decay curves revealed that the first-order decay slope for entire ewes was linear for at least $2 \mathrm{~h}$ and for ovariectomized ewes was linear for up to $24 \mathrm{~h}$ (Fig. 1). The second-order decay slope fell below the assay sensitivity for the ovary-intact ewes and was not apparent in the first $24 \mathrm{~h}$ after hypophysectomy in ovariectomized ewes so was not included in calculations. The first-order decay rate was determined by linear regression analysis on the data up to $2 \mathrm{~h}$ after hypophysectomy for entire ewes and on all data collected for the ovariectomized ewes. The equation of best fit is given by: $x=\mathrm{A}+\mathrm{B} \log 10 y$ where $x=$ time after hypophysectomy and $y=$ plasma FSH concentration. The half-life refers to the time required for a $50 \%$ decrease in plasma FSH concentration to occur as calculated by the regression equation.

Differences between groups for the half-life of FSH were analysed by $2 \times 2$ factorial analysis of variance.

\section{Results}

Examples of the decay curves of plasma FSH achieved in the respective groups (Fig. 1) indicate the linear decline in plasma FSH concentrations after hypophysectomy. The half-life of plasma FSH was similar in Booroola and control Merino ewes but was increased in both groups after ovariectomy $(P<0.001$; Table 1$)$.

Table 1. The mean \pm s.e.m. half-life (min) of FSH in ovary-intact and ovariectomized Booroola and control Merino ewes

\begin{tabular}{lccc}
\hline & Booroola & Control & Mean \\
\hline Ovary-intact & $103 \pm 14^{\mathrm{a}}$ & $116 \pm 8^{\mathrm{a}}$ & $110 \pm 8$ \\
Ovariectomized & $1096 \pm 53^{\mathrm{b}}$ & $1107 \pm 96^{\mathrm{b}}$ & $1101 \pm 49$ \\
\hline
\end{tabular}

Different superscripts denote significant differences, $P<0.001$.

\section{Discussion}

The results of this study indicate that the high ovulation rate of the Booroola ewe is not due to an increased lifespan of FSH in blood plasma. This is consistent with the similar preovulatory concentrations of plasma FSH found in Booroola ewes with and without the gene for fecundity by Bindon et al. (1982) using our current FSH radioimmunoassay. However, other groups have reported differences in FSH concentrations during specific periods of the oestrous cycle using different FSH assays (K. P. McNatty, personal communication). Various chemical forms of FSH have been demonstrated in pituitary extracts (Chappel, 1981; Ulloa-Aguirre \& Chappel, 1982; Zaidi et al., 1982; Wide, 1985a) and these exhibit different biological activities (Peckham et al., 1973; Blum et al., 1985; Wide, 1985b). It is therefore possible that our radioimmunoassay may not be measuring the biologically active FSH which may, in fact, differ between Booroola and control Merino ewes. Assuming the relevance of our assay, there is no difference in the concentration or the half-life of plasma FSH between the two Merino strains, suggesting that the high ovulation rate of the Booroola ewe could be due, at least in part, to a difference at the ovarian level (Fry et al., 1986). 
An accurate calculation of the half-life of FSH in ewes was obtained after hypophysectomy. The rate of clearance of FSH in this closed system was measured over $24 \mathrm{~h}$ and values for half-lives were obtained that were close to the estimate of 102 min determined by measurement of the clearance rate of ${ }^{131} \mathrm{I}$-labelled FSH in white-faced ewes (Akbar et al., 1973).

Ovariectomy caused a 10 -fold increase in the half-life of plasma FSH. The liver is the major site of hormone clearance (Morell et al., 1971) and the ovaries remove only minimal amounts of FSH from the peripheral circulation (Morell et al., 1971; Moore et al., 1972) and so it is most likely that the change in half-life is due to an alteration of the biochemical nature of FSH, and not to elimination of the target organs. Similarly, Montgomery et al. (1984) monitored LH secretion for up to 12 months after ovariectomizing ewes and found that the apparent half-life of $\mathbf{L H}$ in the plasma increased from $28 \mathrm{~min}$ at 1 day after ovariectomy to $63 \mathrm{~min}$ at 1 year. In addition, Peckham \& Knobil (1976a, b) and Weick (1977) have found that the longer half-life species of LH may be of higher molecular weight. The molecular nature of FSH in ovary-intact and ovariectomized ewes is currently under investigation.

The two half-life forms of FSH observed in this study could both be present in the ovary-intact ewes, with the short half-life form of FSH being readily released, and the longer half-life form corresponding to a second-order decay which falls below the level of our assay sensitivity (Fig. 1). This second order of decay was observed by Yen et al. (1970) after surgical hypophysectomy of women. This presents the possibility that the pattern of FSH release is biphasic, similar to that of LH (Fraser, 1979). If both half-life forms of FSH are present in the pituitary gland it would be interesting to see whether their release patterns are the same or different.

We conclude that there is no difference in the half life of FSH between Booroola and controlstrain Merino ewes but that long-term ovariectomy has a major influence on the half-life of this hormone. It remains to be determined whether this longer half-life form of FSH secreted by ovariectomized ewes is more heavily glycosylated and may consequently have a longer half-life in 'normal' ewes, indicating that this form may have an increased biological potency in the ewe.

We thank Mr P. Weston, Mr T. Gill and Mr P. Langdon for technical assistance. This study was funded by the Wool Research Trust Fund of the Australian Wool Corporation and the National Health and Medical Research Council of Australia.

\section{References}

Akbar, A.M., Nett, T.M. \& Niswender, G.D. (1973) Metabolic clearance and secretion rates of gonadotropins at different stages of the estrous cycle in ewes. Endocrinology 94, 1318-1328.

Bindon, B.M. (1984) Reproductive biology of the Booroola Merino sheep. Aust. J. biol. Sci. 37, 163-189.

Bindon, B.M., Findlay, J.K. \& Piper, L.R. (1982) Preovulatory plasma FSH in high fecundity Booroola ewes. Proc. Aust. Soc. Reprod. Biol. 14, 84, Abstr.

Blum, W.F.P., Riegelbauer, G. \& Gupta, D. (1985) Heterogeneity of rat FSH by chromatofocusing: studies on in-vitro bioactivity of pituitary FSH forms and effect of neuraminidase treatment. J. Endocr. $105,17-27$.

Bremner, W.J., Findlay, J.K., Lee, V.W.K., DeKretser, D.M. \& Cumming, I.A. (1980) Feedback effects of the testis on pituitary responsiveness to luteinizing hormone-releasing hormone infusions in the ram. Endocrinology 106, 329-336.
Chappel, S.C. (1981) The presence of two species of follicle-stimulating hormone within hamster anterior pituitary glands as disclosed by concanavalin A chromatography. Endocrinology 109, 935-941.

Clarke, I.J., Funder, J.W. \& Findlay, J.K. (1982) Relationship between pituitary nuclear oestrogen receptors and the release of $\mathrm{LH}, \mathrm{FSH}$ and prolactin in the ewe. $J$. Reprod. Fert. 64, 355-362.

Clarke, I.J., Cummings, T.J. \& DeKrester, D.M. (1983) Pituitary gland function after disconnection from direct hypothalamic influences in the sheep. Neuroendocrinology 36, 376-384.

Davis, G.H., Montgomery, G.W., Allison, A.J. \& Kelly, R.W. (1982) Segregation of a major gene influencing fecundity in progeny of Booroola-sheep. N.Z. J. agric. Res. 25, 525-529.

Fraser, H.M. (1979) Releasing hormones. In Reproduction in Mammals, Book 7, pp. 1-52. Eds C. R. Austin \& R. V. Short. Cambridge University Press, Cambridge. 
Fry, R.C., Clarke, I.J., Cummins, J.T., Bindon, B.M., Piper, L.R. \& Cahill, L.P. (1986) Induction of ovulation in hypophysectomized Booroola ewes. Proc. Aust. Soc. Reprod. Biol. 18, 48, Abstr.

Lee, V.W.K., Cumming, I.A., de Kretser, D.M., Findlay, J.K., Hudson, B. \& Keogh, E.J. (1976) Regulation of gonadotrophin secretion in rams from birth to sexual maturity. J. Reprod. Fert. 46, 1-6.

Montgomery, G.W., Crosbie, S.F., Martin, M.R.C. \& Pelletier, J. (1984) Changes in the clearance rate of immunoreactive LH after ovariectomy in Ile-deFrance ewes. In Reproduction in Sheep, pp. 23-25. Eds D. R. Lindsay \& D. T. Pearce. Australian Academy of Science, Canberra.

Moore, R.T., Mohrmam, D.E. \& Niswender, G.D. (1972) Variations in the blood flow to the ovaries of sheep during the oestrous cycle. Excerpta Med. Int. Congr. Ser. 256, 64, Abstr.

Morell, A.G., Gregoriadis, G. \& Scheinberg, I.H. (1971) The role of sialic acid in determining the survival of glycoproteins in the circulation. J. biol. Chem. 246, $1461-1467$.

Peckham, W.D. \& Knobil, E. (1976a) Qualitative changes in the pituitary gonadotropins of the male rhesus monkey following castration. Endocrinology 98, 1054-1060.

Peckham, W.D. \& Knobil, E. (1976b) The effect of ovariectomy, oestrogen replacement and neuraminidase treatment on the properties of adenohypophysial glycoprotein hormones of the rhesus monkey. Endocrinology 98, 1061-1064.

Peckham, W.D., Yamaji, T., Dierschke, D.J. \& Knobil, E. (1973) Gonadal function and the biological and physicochemical properties of follicle-stimulating hormone. Endocrinology 92, 1660-1666.

Piper, L.R. \& Bindon, B.M. (1980) The Booroola Merino and the performance of medium non-Peppin crosses at Armidale. In The Booroola Merino, pp. 9-19. Eds L. R. Piper, B. M. Bindon \& R. D. Nethery. C.S.I.R.O., Melbourne.
Ulloa-Aguirre, A. \& Chappel, S.C. (1982) Multiple species of follicle-stimulating hormone exist within the anterior pituitary gland of male golden hamsters. J. Endocr. 95, 257-266.

Ulloa-Aguirre, A., Miller, C., Hyland, L. \& Chappel, S. (1984) Production of all follicle-stimulating hormone isohormones from a purified preparation by neuraminidase digestion. Biol. Reprod. 30, 382-387.

Weick, R.F. (1977) A comparison of the disappearance rates of luteinizing hormone from intact and ovariectomized rats. Endocrinology 101, 157-161.

Wide, L. (1985a) Median charge and charge heterogeneity of human pituitary FSH, LH and TSH. I. Zone electrophoresis in agarose suspension. Acta endocr., Copenh. 109, 181-189.

Wide, L. (1985b) Median charge and charge heterogeneity of human pituitary FSH, LH and TSH. II. Relationship to sex and age. Acta endocr., Copenh. 109, 190-197.

Yang, W.H. \& Papkoff, H. (1973) Effect of desialylation on ovulating inducing activity of ovine interstitial cell-stimulating hormone, ovine follicle-stimulating hormone, pregnant mare's serum gonadotrophin, and human chorionic gonadotropin in the hamster. Fert. Steril. 24, 633-639.

Yen, S.S.C., Llerena, L.A., Pearson, O.H. \& Littẹll, A.S. (1970) Disappearance rates of endogenous folliclestimulating hormone in serum following surgical hypophysectomy in man. J. clin. Endocr. Metab. 30, 325-329.

Zaidi, A.A., Froysa, B. \& Diczfalusy, E. (1982) Biological and immunological properties of different molecular species of human follicle-stimulating hormone: electrofocusing profiles of eight highly purified preparations. J. Endocr. 92, 195-204.

Received 5 May 1987 